\title{
Analysis of the Export Potential of Small and Medium Enterprises in the Republic of Serbia
}

\author{
Svetlana Trajkovic, Ljiljana Stosic Mihajlovic* \\ Nis Department, Academy of Technical and Educational Vocational Studies, Vranje, Serbia \\ Email address: \\ svetlana.trajkovic@akademijanis.edu.rs (S. Trajkovic), ljiljana.stosic.mihajlovic@akademijanis.edu.rs (L. S. Mihajlovic) \\ ${ }^{*}$ Corresponding author
}

To cite this article:

Svetlana Trajkovic, Ljiljana Stosic Mihajlovic. Analysis of the Export Potential of Small and Medium Enterprises in the Republic of Serbia. International Journal of Business and Economics Research. Vol. 10, No. 5, 2021, pp. 171-177. doi: 10.11648/j.ijber.20211005.12

Received: September 6, 2021; Accepted: September 22, 2021; Published: October 12, 2021

\begin{abstract}
The long-term stagnation of Serbia's exports is a limiting factor for further economic growth. Therefore, increasing exports is seen as a development necessity. The trend of international networking and multicultural business environment represents a new type of requirement for the management of Serbian companies, both at the national and local level. Their main goal is to contribute to a more efficient integration of the domestic economy into global trade and production flows. In this way, exports become one of the most important determinants of successful and sustainable economic development. Only $30 \%$ of companies in the tradable sector of the Serbian economy are active exporters, while the remaining $70 \%$ of companies are oriented exclusively to doing business in the country. Although most small and medium-sized companies in the tradable sector are exporters, a relatively small number of micro-enterprises have managed to expand their business abroad, which has had a significant impact on the relatively low share of exporters in the total number of companies in Serbia. In general, exporters are more successful and dynamic, as well as twice as productive, as non-exporting companies. The main goal of this paper is to identify the sector of small, medium enterprises and entrepreneurs (SMEs) with development potentials to increase exports and thus create the conditions for these potentials to be used to a greater extent than before. In this way, SMEs can be helped to increase their competitiveness in the international market. This will enable SMEs to make and make a greater contribution to the development of the domestic economy, as well as to broader economic and social priorities. In addition, this paper should indicate which sectors have obvious market potential but at the same time difficulties in achieving their goals and fully realizing that potential. The results of this research should help to design various actions whose implementation would provide adequate support to the identified sectors while minimizing the constraints faced by these sectors.
\end{abstract}

Keywords: Small and Medium Enterprises, Exports, Market, Serbia

\section{Introduction}

The collection of quantitative data for the purposes of this Study was performed by analyzing the available literature via the Internet, but other sources were also used to obtain relevant data. An analysis of available research papers, analyzes and studies, as well as strategic documents related to the relevant field in Europe and especially in Serbia, was performed. For the analysis of the collected data, the method was used - analysis of the content of documents. The main source of statistical data are the publications of the Republic Statistical Office of Serbia. The methodological approach of the analysis of statistical data on the value of export volume realized by the Republic of Serbia through two classifications of sectors - activities: SITC (Standard International Trade Classification) and KD (classification of activities) was used.

The period of the last 5 years has been observed and sectors have been identified - activities that achieve continuous growth in the value of exports.

Talking about the business environment, Jovanovic says that few factors can slow down managers' reactions and limit their ability to anticipate change business environment. These factors include [1]:

1. Cognitive limitations and problems associated with observation and interpretation, and responding to 
changing environments,

2. Managers tend to emphasize learning at a low level over a high level learning,

3. A tendency to nurture organizational employment and promotion practices homogeneity in manager's opinion, and

4. The power of institutionalized industrial practices to focus managerial attention to the status of kuo.

Two authors [2] in the paper analyzed the business conditions in the Southeast Europe region countries and came to the following conclusion: Entrepreneurship represents the basis of the economic activities of developed countries. It has an influence on economic development and an increase in employment rates by generating new jobs. Creating new jobs is the entrepreneurial aspiration for achieving the growth of an entrepreneurial venture. The impact of personal characteristics of entrepreneurs on the development of entrepreneurial venture aspirations in the form of high growth is evident. However, not only the influence of psychological characteristics but also the influence of demographic characteristics, the characteristics of the entrepreneurial enterprise and the business environment within which it exists, is evident. Why do some entrepreneurs show a greater tendency towards the aspirations for the growth of an entrepreneurial enterprise, which factors influence the development of this type of entrepreneur's aspiration? These research questions represent the unlimited potential for future research ventures, at least as far as entrepreneurial aspirations are concerned, a more concrete growth of entrepreneurial endeavors.

\section{General Information on the SME Sector in Serbia}

In 2013, the SME sector maintained a relatively high share in the education of basic business indicators of the nonfinancial sector of the economy of the Republic of Serbia: it generates about $2 / 3$ of employment and turnover, $54.1 \%$ of gross social value (hereinafter: GVA) and participates with $43,2 \%$ in exports of the nonfinancial sector. It is estimated that in 2013, the SME sector, which accounts for $99.8 \%$ of the total number of economic entities, participated with about $34 \%$ in the gross domestic product (hereinafter: GDP) of the Republic of Serbia. Observed by size in the structure of the SME sector, the most numerous are micro enterprises, which participate with $96.2 \%$ in the total number of SMEs [3]. The relatively low average number of 2.4 employees per business entity indicates one of the key weaknesses of the SME sector compared to EU Member States, where the average is 4.2. In the structure of the SME sector, the most numerous are micro enterprises $(305,321)$, small and medium-sized companies $(11,841)$, and at the same time these companies dominate in the following indicators [4]:

1. $53.8 \%$ employment of the SME sector,

2. $60.7 \%$ turnover of the SME sector,

3. $61.6 \%$ of GDP of the SME sector,

4. $77 \%$ of exports of the SME sector.

The Serbian economy is characterized by a large disproportion in the level of economic development between the region and the area, which in the long run is a major development constraint. Although SMEs dominate in all regions and most regional areas of Serbia, their concentration in more economically developed regions and areas is noticeable. SMEs of the most developed Belgrade region make up $1 / 3$ of the total number and employ $1 / 5$ of the total employment of the non-financial sector. Observed according to GVA per employee, the SME sector in the Belgrade region is 2.0 times more productive compared to the region of Southern and Eastern Serbia, 1.7 times higher than the region of Sumadija and Western Serbia and 1.3 times higher than the region. Vojvodina. Great unevenness in the achieved level of development also exists at the district level. The GVA ratio per employed SME of the most developed (Belgrade) area and the least developed (Pcinja) area is 2.3: 1 .

Table 1. Structure of the SME sector compared to the EU.

\begin{tabular}{|c|c|c|c|c|c|c|}
\hline \multirow{3}{*}{$\begin{array}{l}\text { Indicator } \\
\text { Region } \\
\text { Size } \\
\end{array}$} & \multicolumn{3}{|c|}{ Number of enterprises } & \multicolumn{3}{|c|}{ Employment } \\
\hline & \multicolumn{2}{|l|}{ Serbia } & \multirow{2}{*}{$\mathbf{E U}$} & \multicolumn{2}{|l|}{ Serbia } & \multirow{2}{*}{$\mathbf{E U}$} \\
\hline & Number & $(\%)$ & & Number & $\%$ & \\
\hline Micro & 303.927 & 96,2 & 92,2 & 591.101 & 42,0 & 29,7 \\
\hline Small & 9.353 & 3,0 & 6,5 & 181.033 & 12,9 & 20,6 \\
\hline Medium & 2.132 & 0,7 & 1,1 & 223.367 & 15,9 & 17,2 \\
\hline MESP & 315.412 & 99,8 & 99,8 & 995.501 & 70,8 & 67,5 \\
\hline A big & 494 & 0,2 & 0,2 & 410,403 & 29,2 & 32,5 \\
\hline In total & 315.906 & 100 & 100 & 1.405 .904 & 100 & 100 \\
\hline
\end{tabular}

Source: Ministry of Economy based on the SBS [5].

Slowed dynamics of development and reduction of the number of economic entities in the SME sector are the result of difficult business conditions, reduced opportunities for financing the SME sector and declining foreign demand, due to reduced overall business activity of Serbia's most important foreign trade partners (EU member states and other countries).

\section{Overview of Serbian International Trade and Export Competitiveness}

Export competitiveness is influenced by a large number of factors (productivity, production costs, technological 
development and level of production, etc.), but it is predominantly determined by the level of industrial competitiveness. Industrial competitiveness dominantly affects the overall competitiveness and is the basis of export competitiveness.

The achieved level of industrial competitiveness is monitored on the basis of the analysis of structure and productivity according to the technological complexity of production. Within the processing industry in Serbia, the sectors of lower technological complexity and lower productivity (labor and resource-intensive activities) dominate, with the situation being less favorable for SMEs compared to large enterprises.

Facts on Serbia's export competitiveness [6]:

1. Serbia as a whole recorded positive competitiveness in the post-crisis period.

2. Serbia's export position has improved in $70 \%$ of export destinations.

3. Most of the most competitive sectors are resource intensive (production of plastic and rubber products; production of metal products; production of wood and paper; production of coke; production of petroleum products).
4. Serbia achieves the largest detected comparative advantage in the agricultural and agribusiness sectors.

5. Most areas in the agricultural and agribusiness sectors have not been able to improve or at least maintain their previously acquired export positions in foreign markets.

6. The competitiveness of most top-ranked sectors was based on a small number of companies.

7. The vast majority of the most competitive sectors exhibit a moderate or high degree of concentration.

8. A total of $85 \%$ of large, $71 \%$ of medium and $51 \%$ of small enterprises are exporters (in the tradable sector; 2014 data).

9. Exporters are generally more successful, productive, profitable and dynamic than non-exporting firms.

10. Many of the most competitive sectors rely on foreign direct investment.

In 2015, SMEs from the sector of high and medium high technological complexity make up only $10 \%$ of SMEs in the manufacturing industry ( $28 \%$ large), employ $17 \%$ of workers (32\% large) and generate $21 \%$ of GVA of SMEs in the industrial sector (27\% large).

Table 2. Export-Import 2015-2019.

\begin{tabular}{lll}
\hline Year & Export & Import \\
\hline 2015. & 108,7 & 108,7 \\
2016. & 111,1 & 111,2 \\
2017. & 107,5 & 107,4 \\
2018. & 100,1 & 100,2 \\
2019. & 105,3 & 105,3 \\
\hline
\end{tabular}

Data source: Statistical Yearbook [4].

Table 3. External trade balance.

\begin{tabular}{|c|c|c|c|c|c|c|c|c|}
\hline & \multicolumn{2}{|c|}{ Value, mill. RSD } & \multicolumn{2}{|c|}{ Value, mill. EUR } & \multicolumn{2}{|c|}{ Value, mill. USD } & \multicolumn{2}{|l|}{ Balance of trade } \\
\hline & Exports & Imports & Exports & Imports & Exports & Imports & $\begin{array}{l}\text { Exports minus } \\
\text { imports, mill. USD }\end{array}$ & $\begin{array}{l}\text { Exports, as percentage of } \\
\text { imports }\end{array}$ \\
\hline 2015. & 1453477 & 1942304 & 12039 & 16087 & 13376 & 17875 & -4499 & 74,8 \\
\hline 2016. & 1653758 & 2101528 & 13432 & 17068 & 14883 & 18899 & -4016 & 78,8 \\
\hline 2017. & 1827893 & 2354803 & 15051 & 19396 & 16997 & 21921 & -4923 & 77,5 \\
\hline 2018. & 1925841 & 2592547 & 16282 & 21919 & 19239 & 25883 & -6644 & 74,3 \\
\hline 2019. & 2066880 & 2813880 & 17536 & 238751 & 19633 & 26731 & -7098 & 73,4 \\
\hline
\end{tabular}

Data source: Statistical Yearbook.

Observed individually by country, the trade surplus was realized with the former Yugoslav republics: Bosnia and Herzegovina, Montenegro and Macedonia. Of the other countries, the surplus with Italy, Romania and Bulgaria stands out. The biggest deficit occurs in trade with China (due to the import of telephones for the network of stations and laptops) and the Russian Federation (due to the import of energy, primarily oil and gas). The deficit follows with Germany, Hungary, Poland (import of motor vehicle parts), Turkey, Switzerland, Austria, Belgium [7].

According to the sections (sectors) of the Standard International Trade Classification (SITC), the largest share in exports are: road vehicles (\$1,569.1 million), electrical machinery and appliances (\$1,031.4 million), vegetables and fruits (764.0 million), cereals and their products ( $\$ 638.1$ million) and non-ferrous metals (\$563.1 million).

Exports of these five sections account for $34.2 \%$ of total exports. The first five sections with the largest share in imports are: road vehicles (\$1828.6 million), oil and oil derivatives ( $\$ 1190.3$ million), electrical machinery and apparatus (\$770.0 million), industrial machinery for general use (\$684.1 million) and natural gas (\$617.6 million), and their imports account for $27.9 \%$ of total imports. The unclassified goods section, which now includes goods in the customs warehouse and in the free zone, has a share of $11.7 \%$ in total imports [8].

Based on the available data, we can conclude that the calculation of macroeconomic aggregates includes 298,279 
entrepreneurs who operated during 2020 in the Republic of Serbia. Out of that total number of entrepreneurs, in the Belgrade region in 2020 there were 85,708 entrepreneurs which makes $28.7 \%$, in the Region of Vojvodina 74,062 which makes $24.8 \%$, in the Region of Sumadija and Western Serbia 85,695 - which makes $28.7 \%$, and in the Region of Southern and Eastern Serbia 52,814 entrepreneurs - which is $17.7 \%$.

Observed by sectors KD (2010), at the level of the Republic of Serbia, the largest share in the total number of entrepreneurs had: Wholesale and retail trade; repair of motor vehicles and motorcycles (21.4\%), Manufacturing (14.8\%), Professional, scientific, innovation and technical activities $(13.9 \%)$, Transport and storage $(10.9 \%)$, Accommodation and catering services $(8.4 \%)$, Other service activities (7.8\%), etc. Entrepreneurs in the Republic of Serbia in 2020 employed 272,446 workers. There were 53,908 workers in the Belgrade region - $19.8 \%, 72,302$ in the Vojvodina region - $26.5 \%$, 86,192 in the Sumadija and Western Serbia region - 31.6\%, and in the Southern and Western region. Eastern Serbia 60,043 workers - which is $22.0 \%$ of employees. Observed by sectors KD (2010), the largest share in the total number of employees of entrepreneurs in the Republic of Serbia in 2020 had: Wholesale and retail trade; repair of motor vehicles and motorcycles (29.7\%), Manufacturing (24.6\%), Accommodation and catering services (14.5\%), Professional, scientific, innovation and technical activities (7.3\%), Other service activities $(4.4 \%)$ etc.

The list of the top 10 imported products shows that motor vehicle parts and accessories are our first imported product (\$71 million). The second most important is the import of crude oil (\$67 million). On the third place of the import list is the import of medicines for retail (34 million dollars). Import of cars, diesel, over 1500 , but below $2500 \mathrm{~cm}^{3}$ amounted to 25 mil. dollars. The import of gas oils in the value of $18 \mathrm{mil}$. dollars. 17 million was spent on the import of copper ore and concentrate. dollars. Imports of lubricating oil were 14 mil. dollars, as much as the import of telephones for the station network. The import of natural gas was also worth 14 million. dollars. The last place is occupied by the import of refined copper wire with 10 mil. dollars [9].

When observing the territorial distribution of the realized turnover of entrepreneurs in 2020, it can be noticed that entrepreneurs from the Belgrade region realized $26.5 \%$, the Region of Vojvodina $24.6 \%$, the Region of Sumadija and Western Serbia $31.4 \%$, and from the Region of South and Eastern Serbia $17.5 \%$ of total turnover. Observed by sectors KD (2010), the largest share at the level of the Republic of Serbia in the realized turnover had entrepreneurs from Wholesale and retail trade; repair of motor vehicles and motorcycles (45\%), Manufacturing (19.1\%), Construction (6.7\%), Professional, scientific, innovative and technical activities (6.1\%), Accommodation and catering services $(5.9 \%)$, Other service activities $(4 \%)$, etc.

Entrepreneurs from the Belgrade region participated in 2020 with $29.9 \%$ in GVA, the Region of Vojvodina with $24.7 \%$, the Region of Sumadija and Western Serbia with
$29.2 \%$, while the share of entrepreneurs from the Region of Southern and Eastern Serbia was 16, 2\% of total GVA. Observed by sectors KD (2010), the most significant share in GVA at the level of the Republic of Serbia was achieved by: Wholesale and retail trade; repair of motor vehicles and motorcycles (23.4\%), Manufacturing (17.6\%), Professional, scientific, innovation and technical activities (12.9\%), Transport and storage (7.9\%), Accommodation and catering services (7.4\%), Construction (7.4\%), etc [4].

In the international economy, the basic flows are: exports, imports and net exports - trade balance. Exports are goods and services that are produced in one country and sold to other countries. The difference between exports and imports is net exports or trade balance.

\section{Limiting Factors of Export Growth in Serbia}

Despite the upward trend in merchandise exports, there are a number of problems for exporters and the constraints they face in exports. First of all, these are high interest rates on the domestic market, so that companies only borrow out of necessity. Foreign banks prefer lending to domestic consumption. Restrictive monetary policy (due to inflationary pressures) continues to reduce the credit potential of banks, which in turn makes it easier to keep interest rates high [10]. Lending interest rates of commercial banks are especially high if we take into account low deposit interest rates on deposits. The lack of working capital to finance production is accompanied by a lack of funds to finance and insure export operations, which makes it difficult to expand domestic exports and form a sustainable long-term trend of its growth. In order to remove this limitation, it is necessary to ensure the appropriate financial potential of the Export Insurance and Credit Fund, and to strengthen the state's involvement in the field of export promotion of the economy (provide significant funds in the budget for this purpose). The precondition for a long-term increase in the share of the value of Serbia's merchandise exports in its GDP is the restructuring of the real sector of the economy [11]. The expectation that this process will proceed rapidly thanks to privatization has not yet been convincingly confirmed, as the amount of new investment in the form of imports of modern foreign equipment and technology is still relatively modest. The lag of the domestic economy abroad by several technological cycles cannot be a satisfactory basis for the growth of competitive exports. Therefore, we must not lose sight of the interest shown by foreign buyers of domestic companies, primarily for the domestic market, and only then for exports (steel exports are an exception because, above all, they are service processing jobs). Privatized foreign-owned companies often become net importers [12]. Although these liberalization measures have contributed to a stronger connection of the domestic economy with foreign countries, their consequences have been felt primarily in the domestic market because there has been a more dynamic growth of 
imports compared to the growth of exports in the period after 2000. The increase in the openness of the domestic economy has influenced the strengthening of competition in the domestic market, with a noticeable neglect of exports. Some of the more prominent problems in achieving better export results are [13]:

Insufficient competitiveness of exports Despite relatively lower wages compared to developed countries and new EU members, companies in Serbia are characterized by marked slowness in the introduction of new products due to insufficient innovative activity in companies and due to relatively low levels of FDI. The technological level of most of Serbia's exports is not adjusted to strong competition on the world market, and the action of non-price factors (sales market research, application of quality standards) has not yet become an important factor in export success.

Unfavorable investment climate Still unfavorable investment climate (according to foreign investors) may affect the growth of operating costs, which directly affects the competitiveness of companies in Serbia, and adversely affects the formation of new export-oriented companies and FDI inflows into these sectors. In addition to all the above, we should add the modern crisis caused by the COVID-19 pandemic. A significant number of crisis situations arise due to the inability of management to anticipate changes that occur in the environment [15].

\section{Sectors with the Greatest Economic Potential in Serbia}

The sectors with the greatest potential in Serbia are those that provide companies with adequate resources with which they are able to systematically produce internationally competitive products while their business is at the same time profitable, productive and dynamic. Such sectors encourage the development of competitive firms whose growth will be able to boost the Serbian economy as a whole; therefore, we consider these sectors to be the most suitable for the development of companies. This does not mean that every company that is part of an industry with potential will really be successful and competitive internationally. Nevertheless, the average firm has a better chance of succeeding within such a sector. Whether a company will succeed or not depends primarily on the individual attributes of that company itself.

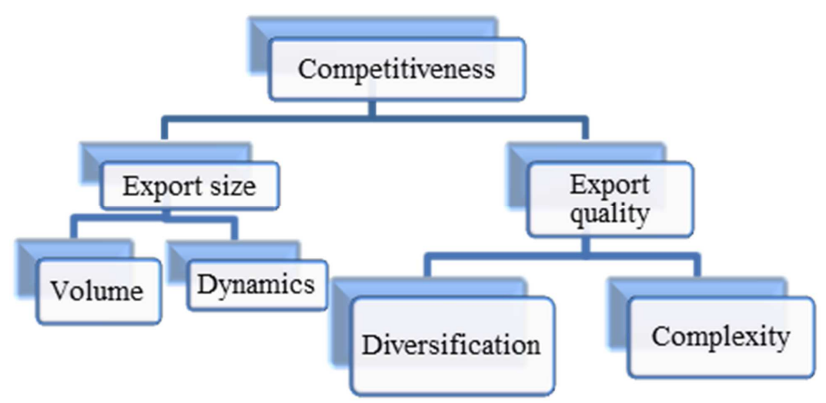

Figure 1. Key determinants of voluntary competitiveness.
Exporters face numerous problems in business, where the unstable exchange rate, large debts to them, as well as numerous administrative obstacles are mentioned. It is necessary to create a favorable and stable business environment, and it is important to work on encouraging as many companies as possible to export, with favorable loans to finance exports. Proposed measures to increase Serbian exports are: strengthening the marketing of Serbian products, providing additional financial support, improving customs and other cross-border procedures, reducing taxes and contributions and continuous training and education of employees. What do companies need to increase exports? Needed: information on foreign markets and export issues, improvement of regulations in the field of exports, connection with potential partners and mutual networking.

The sectors with the greatest potential were identified based on the integration of the results of two complex analyzes - export performance analysis and performance analysis of the sector as a whole. The ultimate goal of the analysis is to identify sectors that possess the resources and capabilities necessary for strong, dynamic, diversified and sustainable exports. Success in foreign markets is a clear reflection of the systematic ability of one sector to produce a competitive product, but at the same time to continuously improve its market position in conditions of competition from other countries. From the model of export performance and its determinants - competitive advantages, comparative advantages, product complexity and export diversification we can report certain general conclusions about the international business of the Serbian economy. It can be concluded that the export competitiveness of Serbia as a whole has been systematically and comprehensively improved in the observed post-crisis period. The export position, measured through an increase in market share, has improved to over $70 \%$ of the most important export destinations. However, it is also indicative that this performance was predominantly based on the operations of a small number of tradable sectors, primarily the highly competitive automotive industry. Other most competitive sectors mainly belong to resource-intensive areas (plastics, rubber, metal products, wood and paper, coke, petroleum products). Although agriculture and agribusiness are among the sectors most important for exports from Serbia, when we look at their performance through the prism of competitiveness, we can see that agriculture and agribusiness were not able to compete with rivals in the post-crisis period, from 2009 to 2013. How do we measure the potential of the sector? 5 We measure the potential of the sector using an index composed of four main components: achieved performance, potential for economic development, contribution to socio-economic goals and expert opinions. The components are complementary and successively enhance each other's effect [14].

Achieved performance shows the effect that companies have achieved in the market in the observed period. The component indicates how much companies within the sector have been able to cope with the negative consequences of the 
crisis, to grow and develop dynamically, operating successfully within their "core" business.

The potential for further economic development "corrects" the performance achieved in the past for new expectations, emphasizing the "effect" of the positive trend in those who are expected to prosper in the future and highlighting those who encourage others to grow by their own prosperity.

Contributing to socio-economic goals, building on what has already been achieved and expected in the future, gives special importance to sectors that have the capacity to help achieve national priorities.

Expert opinions include a dose of experience and subjectivity, which aims to correct data imperfections, methodologies, approximation processes and other "failures" by relying solely on quantitative indicators.

\section{Ranking of Sectors in Serbia According to Development Potentials}

The initial production capacity in the economy, economic theory describes by utilization two factors of production capital and labor. The end result is an aggregate supply or national output in the long run. With the change in total capital funds we also have changes in the dynamics of the output. Higher production, ie. gross domestic growth products, as the broadest aggregate of economic activity in a country, is possible achieved by expanding capital funds (physical and human).[16]

The research, conducted in 2014 by the Center for Advanced Economic Studies (CEVES) in cooperation with the Serbian Chamber of Commerce (SCC), identified sectors with high development potential - composed of competing firms, and should be the driving force behind the development of Serbian economy [9]. The final results of the index are presented through the ranking of 114 sectors according to their development potentials. The final ranking of the sector reflects the development potentials of the sector according to their achieved competitiveness, the ability to transfer their growth to the rest of the Serbian economy and to contribute to the development of socio-economic goals.

The new economic reality has led the EU to the need to change the economic paradigm that equates the importance of economic growth and environmental protection through sustainable investments based on saving resources and maximum use of materials in circulation. Serbia's economy relies heavily on trade with the EU and investment from the EU, especially from Germany and Italy. For example, in February 2020 , total exports reached almost 1.5 billion euros, but fell by almost a third to about a billion euros in April 2020 [17].

The sectors that stood out in the top 10 according to development potentials are: motor vehicle production; manufacture of electrical and electronic equipment for motor vehicles; production of socks; household appliances; processing and canning of fruits and vegetables; manufacture of tires for vehicles; electricity generation; general purpose machines; animal food; and manufacture of paper, pulp and paperboard. Among them, 7 sectors are concentrated, which means that their growth is mostly determined by the operations of one or a smaller number of companies. The sectors that showed the lowest development potential are: other precious and non-ferrous metals, accumulators and batteries; art and culture; aluminum production; glass products; ceramic products; coal exploitation; other animals; gas production and distribution.

\section{Conclusion}

By researching and analyzing relevant facts and data, the paper aims to identify the export potential of certain sectors and support the creation of a new, long-term, innovative service for SMEs based on their real needs and which will strengthen their business capacity and contribute to conquering new markets. Based on the analysis of basic indicators on the state and development of entrepreneurship, it can be concluded that entrepreneurs are a significant segment of the overall economy, have an increasingly significant share in the economic structure, and continuously increase their influence on GVA and turnover. Incentive measures adopted by the Government will create conditions for further work and development of entrepreneurship and will provide an opportunity for every entrepreneur who has a viable business idea to be able to realize it on the relevant market, under the best possible conditions. What do companies need to increase exports? Needed: information on foreign markets and export issues, improvement of regulations in the field of exports, connection with potential partners and mutual networking.

\section{References}

[1] Jovanovic, Z. (2015). Management and changes in business Environment. Ekonomika 61 (2), 143-151.

[2] Petrović, M., \& Leković, B. (2019). Characteristics of ambitious entrepreneurs in Southeast Europe region: highgrowth expectation concept. Anali ekonomskog fakulteta $\mathrm{u}$ Subotici, Vol. 55, broj 41/2019, 55-66.

[3] Entrepreneurs in the Republic of Serbia, no. 117, Year LVII, Republic Statistical Office, Belgrade, 2021. https://publikacije.stat.gov.rs/G2021/Pdf/G202110117.pdf

[4] STATISTICAL YEARBOOK (2020). Statistical Oce of the Republic of Serbia, / Belgrade, pp. 260-302.

[5] Ministry of Economy based on SBS (2020). Belgrade 2020.

[6] REAL SECTOR PERFORMANCE IN SERBIA (2021). Competitiveness by size, sector and region, pp. 36 .

[7] Sormaz, N., Bobić D. (2019). Center for Advanced Economic Studies, "Index of development potentials of tradable sectors in Serbia - IRP". pp. 95.

[8] Udovicki, K., Sormaz, N., Bobic, D, Bozovic, B. (20142019). Center for Advanced Economic Studies, "REAL SECTOR PERFORMANCE IN SERBIA: Expressed competitiveness by size, sector and region, pp. 23-27. 
[9] Ministry of Economy National Agency for Regional Development, "Report on Small and Medium Enterprises and Entrepreneurship for 2017", pp. 18.

[10] Center for Advanced Economic Studies (CEVES), (20152019). Potential and prerequisites for the growth of the SME sector in Serbia, Belgrade, pp. 16-21.

[11] Stosic Mihajlovic, Lj. Market, costs and prices, Academy of Technical Education Vocational, Nis, pp. 136-140.

[12] USAID Sustainable Local Development Project (SLDP), SME Competitiveness Report in Serbia.

[13] Gagović, N. (2019). Determinants of export growth and analysis of the possibility of increasing exports of Serbia, Belgrade, pp. 16-19.
[14] Ministry of Economy - Serbia. (2014). Strategy to support the development of SMEs, entrepreneurship and competitiveness for the period from 2015 to 2020", Belgrade, pp. 3-14.

[15] Jevtic, P., Stosic Mihajlovic, Lj., Latin, R. (2020). Moderni krizni marketing menadžment. Ekonomski Izazovi, vol. 9, br. 18 , str. $110-120$

[16] Nikolic, I (2019). Stanogradnja u Srbiji - razvojni potencijali i ograicenja. Ekonomski institut, Beograd, ISBN: 978-86-7329-110-9, pp. 3-20.

[17] Kamberovic, S., Mitrovic, S., Behrens, A., (2020). GAP analysis of opportunities for economic strengthening through the application of sustainable business models after the COVID-19 pandemic in the Republic of Serbia Publisher: OSCE Mission to Serbia. 